\title{
A labeling system as stepping stone for incentives related to the profitability of sustainable housing
}

\author{
J. D. M. van Hal
}

Received: 1 December 2006/Accepted: 1 June 2007/Published online: 9 September 2007

(C) Springer Science+Business Media B.V. 2007

\begin{abstract}
In 2004, the Dutch National Sustainable Building Center set up a research project to investigate the widespread belief that sustainable building is more expensive than standard building practice. The results disproved this assumption and demonstrated that sustainable building can be financially profitable. However, the research also showed that these positive financial aspects are hardly ever used to promote sustainable building. SenterNovem initiated a new research project in order to recommend practical solutions for the identified issues. Besides the sustainable and 'regular' building sectors, the new project included other sectors in an effort to develop new insights. Focused on housing, this second project revealed the inevitability of a labeling system that covers all activities ('one language'). It recommends giving top priority to the introduction of a labeling system that translates sustainability in housing into a manageable and controllable system. The system should clearly identify the level of sustainability of a specific house. To gain acceptance among consumers, the system would have to tie in with consumer needs. The idea that many financial incentives can be linked to this labeling system was affirmed in a separate workshop. Just before the second research project was completed, the Dutch housing corporation Oost Flevoland Woondiensten (OFW) introduced a labeling system for their entire stock related to the topics of energy and health. Nine months after the launch, an assessment of this labeling system confirmed the results of the theoretical research and the workshop.
\end{abstract}

Keywords Housing · Labeling system · Energy efficiency · Sustainability · Financial incentives

J. D. M. van Hal (ه)

Faculty of Architecture, Delft University of Technology, Delft, The Netherlands e-mail: ankevanhal@planet.nl

URL: www.ankevanhal.nl

J. D. M. van Hal

Consultancy Anke van Hal, Dorpsweg 146, Maartensdijk 3738 CK, The Netherlands 


\section{Introduction}

According to Dutch housing corporations, sustainable housing is more expensive than standard building practices. For that reason, and because of the lack of consumer demand, they do not customarily build sustainable housing. This is one of the main conclusions of a Dutch investigation (Sunikka and Boon 2002). In light of the prevailing negative opinion on its cost effectiveness among Dutch housing corporations and other professionals, the Dutch National Sustainable Building Center (SBC, now part of SenterNovem) decided to conduct a research project. The objective was to identify indicators to support or reject the hypothesis that sustainable building is more expensive than standard building practice (Boon et al. 2004). The conclusion was that whereas sustainable building can be profitable (see chapter 2), it is rarely carried out due to various obstacles.

However, the research did not indicate how to overcome these obstacles. At the end of 2005, further research was therefore undertaken by SenterNovem (Hal 2006). This time, the objective was to generate practical solutions that would improve the chances of profit. The present article describes the results of this latest research. It starts with some background information on the profitability of sustainable building and ends with a discussion on the effectiveness of the research results.

\section{The profitability of sustainable building}

Sustainable building is premised on the implementation of preventive innovations. Rogers (1995) notes the difficulty of developing preventive innovations-i.e., innovations that lead to 'eventual' savings. Not only does it take time before actual benefits appear, but the greater the perceived relative advantage of an innovation, the more rapid its rate of adoption will be. The relative advantage is the degree to which an innovation is perceived as better than the idea it supersedes. According to Rogers, the degree of relative advantage may be measured in economic terms, although social prestige, convenience, and satisfaction are also important factors. However, the thesis Beyond the demonstration project, the diffusion of environmental innovations in housing (Hal 2000), based on the innovation diffusion theory of Rogers, concludes that financial advantage is by far the most important of all relative advantages of environmental innovations in housing.

No general facts and figures are available on the costs of sustainable housing in the Netherlands. One reason is the wide range of options for environmental topics and housing typologies. Another is the diversity of influences, such as location and the volume of the housing project. But other conditions also hinder an easy calculation of general facts and figures. The main ones are the following: time span; level of ambition; environmental costs; phase in which sustainable building has been put on the agenda; and benefits from influence on health. These five conditions are elaborated in the next five subsections, followed by some brief conclusions.

\subsection{Time span}

The time span of a housing project makes it hard to generate general facts and figures on the costs of sustainable building. If an audit is focused on the investment stage of the project, it will come up with completely different figures than one focused on the life cycle of the same building (Infoblad 2006a). For example, a sustainable heating installation, 
based on a collective heat pump and low-temperature heating, is more expensive than a regular high-efficiency central heating system. The cost-recovery time, however, is only 4.5 years for an apartment and 6 years for a single-family house. Moreover, the comfort level of the dwelling is much greater with the sustainable heating system than with the regular heating system (also because of the cooling possibilities). Based on recent gas prices, a heat-pump installation for a single-family house would cost almost $600 €$ less per year than the traditional system (Infoblad voorbeelden 2006c). Higher energy prices do have a positive influence on the cost-recovery time. To give an indication, between 2000 and 2005 , the price of gas rose by $68.7 \%$, while the price of electricity rose by $33.8 \%$ over the same period (CBS 2006).

Other indicators show that a focus on the life cycle of a building can make a sustainable building more cost-effective. A Report to California's Sustainable Building Task Force finds that an upfront investment of less than $2 \%$ of construction costs yields life-cycle savings of over 10 times the initial investment (Cats et al. 2003).

Certainly, taking the whole life cycle of a building into account is the most informative but also the most complex approach. Van de Dobbelsteen (2002) looks at the whole life cycle of the building and distinguishes seven different cost levels: development and design costs; material, installation, and building costs; energy and water costs; maintenance and repair costs; replacement costs; demolition and waste disposal costs; and the residual value. According to that study, development and design costs in a sustainable housing project are often higher because of the extra amount of time necessary for research and preparation. Also the material, installation, and building costs are often higher because of the use of new materials and products, which lack standardization. In contrast, the costs for energy and water at the consumer stage and the demolition and waste-disposal costs are almost always lower. According to Van de Dobbelsteen, no general conclusions can be drawn about the level of maintenance, repair, and replacement costs or about the residual value. Their level depends on the details of the specific project.

The Dutch construction company Panagro has no doubts about the profitability of sustainable building when life-cycle thinking is integrated in the project. As Director Hiddes explains, "It is our goal to keep the future living costs on an acceptable level by investing in energy-saving measures. The energy prices are rising already and this will continue. Saving energy is the easiest way to save money. By choosing innovative insulation materials, extreme energy-saving glass, reusing the heat from ventilation air, and by using terrestrial heat, we can reduce the energy consumption by $90 \%$. This prevents our children from having to spend at least $40 \%$ of their income on energy" (Müller et al. 2006). According to Hiddes, value development is also an argument in favor of sustainable building. "We refuse to build houses for 130,000€. These are hen houses with a negative value development. It is better to build houses of $175,000 €$ with a market value of $220,000 €$. It is easy to finance houses like these (without risk and consequently at a low interest rate). Afterwards their value will rise too. Collective funding and insurances and a lower energy use also make them attractive for starters on the housing market. After 10 years the value of their house makes it possible to move to a more expensive house" (Müller et al. 2006).

\subsection{Level of ambition}

The ambition level of sustainable building also determines the costs. Generally speaking, the higher the ambition, the higher the costs. 
The expression 'factor 20', often heard in connection with sustainability, refers to the amount of ambition needed to make a real change. Factor 20 is based on a calculation by the American ecologist Barry Commoner. It means that the efficiency with which we use environmental resources in the year 2040 must be 20 times better than it was in 1990. In other words, the environmental impact per unit of product or service must be 20 times lower. Factor 20 corresponds to an environmental index of $20 \times 100=2000$ in the GreenCalc method (see Sect. 3.3). The current level of our buildings lies between 100 and 200. Experience has shown the limited environmental gains from technical measures, such as using environmentally friendly materials and renewable energy. At constant accommodation costs, these measures do not bring the environmental index beyond about 200 . After that the costs rise rapidly. If we are prepared to pay the additional costs, an environmental index of around 500 is what can be achieved by utilizing all of the technical options. Pursuing the goal of factor 20, sustainable building will always be more expensive than regular building (About GreenCalc 2006).

Many sustainable building measures are already cost-effective at the investment stage. The Dutch national package Sustainable Housing (new housing), for example, contains 135 sustainable building measures, of which approximately half are cost-neutral (Infoblad, relatie nationale pakketten 2006b). However; these measures do not result in a big step forward in the direction of factor 20. One indication is that if all the cost-effective measures from the national package Sustainable Building for Utilitarian Buildings were applied, the environmental impact would be reduced by a factor of 1.3 (Kasteren et al. 2002).

\subsection{Environmental costs}

"What costs do you count?" This question, which influences the financial picture, is answered by Kasteren et al. (2002) as follows. "In common parlance the environmental costs of a building are the costs incurred for environmental protection measures that exceed the statutory requirements. The hidden environmental costs are a completely different story. In fact these are the costs that would have to be incurred to prevent the building having a negative impact on the environment. In other words, the investment costs necessary to prevent environmental effects. As yet, these costs are not actually incurred, in which case projects would be far too expensive. To illustrate the effect of taking into account the hidden environmental costs: Dutch newspapers are nowadays filled with articles that complain about the high investment costs of energy-efficient measures necessary to reach the new energy-efficient goals of the government. In several cities however, a report about the costs that the municipality should make in the future related to climate change, resulted in the conclusion that it is much cheaper to invest in energy-efficient measures now.

"The Dutch GreenCalc method is an environmental accounting model that makes it possible to establish the hidden environmental costs" (Kasteren et al. 2002). GreenCalc was developed to calculate the environmental sustainability of specific buildings. It is a computer model that is divided into four modules: materials; energy; water usage; and mobility. The environmental assessment is translated into costs per $\mathrm{m}^{2}$ over the entire life cycle of the building (construction, exploitation, and demolition) (About GreenCalc 2006). The same Internet site elaborates on this method. "Sustainability is a vague concept. This can be helpful in politics, but when it comes down to brass tacks, as is the case with sustainable building, you want a concept like this to be somewhat more quantified. This is 
why the Rgd (Dutch Government Buildings Agency) developed an environmental index that expresses the sustainability of a building in one number. The index is based on 1990 as the reference year. A building with a 1990 sustainability level has an environmental index of 100 . The higher the level of sustainability, the higher the index. The environmental index of most projects is between 100 and 200. Leading projects achieve 250, and a few exceptions are higher" (About GreenCalc 2006).

\subsection{Phase in which sustainable building is integrated}

Another condition that prevents easy calculation of general facts and figures is the phase in which sustainable building has been put on the agenda. By thinking about the possibilities at an early stage of a project, the costs can be much lower compared to building sustainably later on. Integrated design, which is only possible when innovations are implemented at an early stage, reduces the costs. According to Kasteren et al. (2002), "Because the development of a housing concept, by definition, does not spontaneously arise either during construction or during the design process, this dialogue should primarily take place during the phase that precedes them, at the birth of the initiative. This involves coming up with and thinking through the processes that must be implemented and the housing requirements associated with them, comparing the various options for housing and, conversely, the viability of each option, and working out the initial sketch drafts for one or several options. In the initiative phase you can also opt for a location that is favorably situated in terms of public transport, for renovation rather than new construction, or for far-reaching office innovation instead of a traditional program of so many square meters per employee. As the process advances the options become more limited, as do the opportunities for developing and implementing new concepts. In the initiative phase the options for uses of the building that carry greater or lesser environmental impact are also defined to a great extent."

A case in the utilitarian building sector that confirms this stance is Deventer Hospital in the Netherlands. By integrating environmental innovations in the initiative phase, the extra costs were kept to a minimum (Hal 2004). In housing, the Passive House concept takes sustainability into account from the outset. The concept refers to a construction standard that aims to reduce the heating needs to a point where conventional heating systems are no longer necessary. Passive House technology is well known in Europe. Numerous successful Passive House schemes have been built in Germany, Austria, Sweden, Belgium, France, and several Central European countries. The low energy use shortens the pay-back time. With a higher investment of $8,000 €$ and a rise in the energy price of $7.5 \%$, the payback time is less than a year (Boonstra et al. 2006). Speaking at the seventh PassivhausTagung in Hamburg in 2003, Mario Mettbach, senator from Hamburg/Bundesland, referred to European research that found Passive Houses to be cost-effective (Passiefhuis platform België).

GPR building, like GreenCalc, is a Dutch performance and communication instrument for sustainable building. The results, which are based on LCA measurements, represent performance as expressed in grades (on a scale of 1-10) (GPR building). A conference on GPR building ('Bouwen aan een duurzame toekomst' [Building on a sustainable future]) was recently held in The Hague (22 March 2007), and the participants gave some indications of profitability. Regular houses have a score of 5 . When sustainable measures are integrated at the earliest stage of the project, better performance is possible without incurring extra costs (scores between 7 and 8). For higher scores, extra investment is necessary. 


\subsection{Benefits from influence on health}

A specific point of interest regarding the profitability of sustainable building is the influence of sustainable building measures on the health of people. Recent international research (Wargocki and Seppänen 2006) demonstrates the relation between indoor climate and productivity/sick leave. In this respect, the healthy indoor climate resulting from sustainable building measures proves to be financially very attractive for utilitarian buildings.

\subsection{Conclusions}

As one of the factors affecting the diffusion of environmental innovations in housing, the financial advantage is by far the most important of the relative advantages of innovation. The fact that environmental innovations are preventive hampers their diffusion, since it takes some time before actual benefit can be seen.

It is difficult to generalize about costs related to sustainable building (housing and utilitarian buildings). Based on available information, five general remarks can be made:

- A focus on the life cycle of a building makes sustainable building more profitable than a focus on the investment stage.

- The more ambitious the level of sustainability, the higher the costs.

- The financial picture is changed by taking into account the costs of preventing the building from having a negative impact on the environment (hidden environmental costs) instead of the costs of investing in environmental protection measures that exceed the statutory requirements (environmental costs).

- Thinking about the possibilities at an early stage of a project results in lower costs compared to implementing sustainable building in a later phase.

- A positive influence of sustainable building measures on people's health may generate a big financial advantage.

It should be noted that the influences mentioned in this chapter also came up at the expert meeting and in the course of the literature study of the SBC research. These insights led to the conclusion that sustainable building can be profitable.

\section{The research}

The conclusion of the SBC research forms the basis of the study conducted by SenterNovem in 2006. The SBC concluded that sustainable building can be profitable, though it is rarely put into practice due to various obstacles. The objective of the SenterNovem study was to generate practical solutions to improve the chances of making a profit. The research question was formulated as follows:

What are some practical and realistic solutions for the problem that the potential positive financial yield of sustainable building is hard to realize?

\subsection{Definition of sustainable building}

In this research, sustainable building is defined as the corporate social responsibility (CSR) of the building parties. Changing the abbreviation 'CSR' to 'sustainable building' in a text 
of the 2005 annual report of CSR Netherlands makes it clear why this definition is appropriate.

"Sustainable building has to shake off its image of sandals and woolly socks. It is no longer the expensive toy of sustainability managers. New forms of sustainable building will arise when companies consider it as 'real' entrepreneurship. Companies have to make sustainable building part of their core activities. The most durable way to implement sustainable building is by making money out of it" (MVO 2005).

According to the 2004 annual report of CSR Netherlands (MVO 2004), there are several types of CSR. In this case, where CSR is comparable to sustainable building, these types may be characterized as follows:

1. charity

2. volunteer work by some employees

3. good citizenship of the firm

4. motivator (the management sees immeasurable benefits such as gaining public confidence)

5. source of financial profit (the management sees measurable benefits)

This research focuses on the fourth and fifth types. That the fourth type of CSR can also be very beneficial is shown in a study by the Research Institute of New York University's Stern School of Business. Charles Fombrun of this university found that a 5\% change in a company's reputation is equal to an increase of one to $5 \%$ in its market value (Willard 2005). The focus of the SenterNovem research is on environment-related aspects of corporate social responsibility.

\subsection{Research design}

Originally, the research was concerned with both housing and public buildings, but in the course of the investigation the focus was narrowed to housing. It was carried out in $120 \mathrm{~h}$ and was based on previous work of the researcher (Hal 2000, 2002, 2004).

The research design comprised interviews, a small literature study, and a workshop. During the SBC study of 2004, many of those involved in sustainable building in the Netherlands had already been interviewed on the subject. For the present study, new and inspiring information was sought. Thus, besides sustainable-building specialists, people in other positions within the construction industry were approached, as well as people active in the field of CSR in other industries. In total, ten persons were interviewed.

The literature study started with reports on recent research about the relation between profit in general and sustainable building or CSR (Graafland et al. 2005; VROM-Raad 2005; MVO Nederland 2005; Bouwend Nederland, Regieraad Bouw 2005). Other literature recommended by the interviewees was also studied, such as international books about the benefits of sustainable building and CSR (Abrams 2005; Willard 2005), several articles (e.g., Poel 2003; Postel 2003), and internal business reports. The results of the interviews and literature study were discussed during a workshop attended by persons from various professional groups related to sustainable building. They included representatives of the state, a municipality, the insulation industry, a bank, a real estate broker, a construction company, a housing corporation, a consultancy, and SenterNovem. As an agency of the Dutch Ministry of Economic Affairs, SenterNovem is charged with implementing policies on innovation, energy and climate, and environment and spatial planning. 


\subsection{Results of the research}

The research generated 90 'incentives', or actions that can be taken to improve the chances of profit. The workshop reduced this enormous number to eight, so that the study could focus on the following points:

- An overall quality test for housing to make quality a controllable element of the price negotiations.

- Green Mortgage, Climate Mortgage.

- Discount on (property) tax.

- Integration in the Dutch Funda system (a website that brings together listings of housing stock supplied by real estate brokers and independently sourced neighborhood information), making sustainability a controllable element of price negotiations.

- Private law agreements between the developer and a municipality.

- Objective standards in a design competition.

- Development of affordable and green innovative housing concepts.

- A green rebuild fund.

The introduction of an overall quality test for housing in the Netherlands has been under discussion for years. The idea of integrating a sustainable-housing labeling system into an overall quality grade for housing is very logical. In this way, sustainability in housing would become normal procedure. This overall quality labeling-system should be performance-based (as should the sustainable building labeling system) and should appeal to do-it-yourself handymen and tenants.

It is also logical to link the labeling system with existing financial constructions. One of these, the Green Mortgage, would have to be improved to make it more effective. Another is the recently introduced Climate Mortgage, which relates energy-saving to the interest paid on the mortgage. The labeling system could also be related to the property tax or other taxes. A proven sustainable quality of the house could lead to lower taxes.

The award-winning Funda.nl website is the main resource for Dutch house-hunters. Funda brings together housing stock listings supplied by members of the Netherlands Association of Real Estate Brokers (NVM) and independently sourced neighborhood information. By integrating the labeling system, in its most elementary form, in the Fundasystem, the brokers would be induced to learn more about sustainability. NVM has already started educating them in this field. The courses the NVM offers, combined with accessibly written fact sheets, should make communication with real estate brokers more effective.

Private law agreements can improve the level of sustainability in new construction and in renovation of the existing stock. The labeling system could form the basis for these agreements. If developers are pressed by a municipality to sign such agreements, the municipality itself should try to reduce the extremely high land prices (a real problem for developers in the Netherlands).

It is imperative for design competitions to have objective standards. The labeling system can also be a source of criteria for housing competition among developers. Limiting the number of participants and offering compensation for the 'good' losers would directly and indirectly enhance cost-effectiveness. Such compensation could take the form of $\mathrm{CO}_{2}$ points. The number of points awarded might increase a developer's chance of getting invited to take part in a competition.

A labeling system can further the development of affordable and green innovative housing concepts for the new and existing housing stock. Cooperation between all related professional parties is necessary, perhaps in the form of a consortium. Moreover, a labeling 
system can further the sustainable renovation of private houses, where the main obstacle is the high amount of investment required. As a replacement for the existing Green Fund, a Green Rebuild Fund would make it possible for private homeowners to rebuild sustainably. In this way, a labeling system would also improve the cooperation with banks.

\subsection{Conclusions of the research}

These eight incentives were discussed in two groups of workshop members. Their overall conclusion was that a labeling system covering all these incentives ('one language') is inevitable. It is the main condition for practical and realistic solutions for the problem that the potential positive financial yield of sustainable building is hard to realize. That problem can be resolved by facilitating objective communication about quality.

For that reason, top priority should be given to the introduction of a labeling system that translates sustainability in housing into a manageable and controllable system. Such a system should clearly indicate the level of sustainability at the level of a specific house.

To get this system introduced in the consumer realm, it must be tailored to the consumers. For example, instead of using environmental language-focused on topics such as energy, water, and waste-it should be couched in consumer language, including terminology such as money-saving, flexibility, and health. This labeling system could be initiated by the market (and thus be voluntary) or by the state (and be compulsory). As the state should act in the public interest, initiation by the government seems logical. If labeling were compulsory, sustainable building could become an integrated aspect of the financial picture instead of an (expensive) 'extra'. However, government involvement often slows down the process. 'The market' would also benefit from the introduction of a labeling system. In that light, a quick market initiative, ahead of a government initiative, would be preferable.

\subsection{Follow-up}

At a Dutch conference on sustainable energy, the conclusions concerning the labeling system were discussed with professionals and members of the public in a workshop (Kansrijk et al. 2006). Four professionals, a civil servant, a real estate agent, the director of a housing corporation, and a banker were asked to comment on the following proposition:

"The market and the environment will benefit from a simple and unambiguous labeling system."

Two representatives of consumer organizations were asked to respond to the comments of the professionals. Their observations were followed by a discussion with the audience, and the outcome may be briefly summarized in the following statements:

- A labeling system is necessary to start objective communication about quality but it is no guarantee for meeting consumer wishes.

- Comfort and health are more important incentives for consumers than profit based on sums on a piece of paper.

- The results of sums on paper and practice can differ, so a labeling system based on sums is not necessarily reliable.

- A labeling system should be a great incentive for real estate agents to take the topic of sustainability more seriously. 
- The labeling system should not be exclusively limited to profit derived from energy efficiency; it should also be related to the topic of human health, for example.

- The EU Energy Performance of Buildings Directive (EPBD) is a suitable basis for energy labeling.

- A focus on the existing housing stock is necessary when starting a labeling system.

A poll taken at the end with red (disagreement) and green (agreement) cards revealed that roughly $90 \%$ of the audience agreed with the proposition.

\section{The effectiveness of a labeling system}

\subsection{Experiences in the USA}

Labeling systems for buildings are common in the USA. The most well-known ones are EnergyStar and LEED.

EnergyStar is an energy-efficiency initiative taken jointly by the US Department of Energy and the Environmental Protection Agency (EPA). Based on a building's energy performance, it can be awarded a bronze, silver, or gold Energy Star. EnergyStar consultants guide the builder throughout the process. They check the technical quality of the building while under construction and when it is finished. If the results are good, the building gets the official EnergyStar logo and certificate. The builder can then apply for a grant from the energy company (Hal 2002).

The Leadership in Energy and Environmental Design (LEED) Green Building Rating System $^{\mathrm{TM}}$ is the benchmark for the design, construction, and operation of high-performance green buildings. LEED promotes a whole-building approach to sustainability by recognizing performance in five key areas: sustainable site development; water savings; energy efficiency; materials selection; and indoor environmental quality. The first step to LEED certification is to register the project. A project is a viable candidate for LEED certification if it can meet all prerequisites and achieve the minimum number of points to earn the Certified level of LEED project certification. To do so, a construction project must meet certain prerequisites and performance benchmarks ('credits') within each category. Projects are awarded Certified, Silver, Gold, or Platinum certification, depending on the number of credits they earn (website USGBC).

The National Institute of Standards and Technology (NIST) published an evaluation of the LEED method for rating the energy and environmental performance of buildings as early as 2002 (Scheuer 2002). The following three excerpts from this critical report indicate the significance of labeling systems for buildings.

"The LEED method is currently the best overall tool available for rating the energy and environmental performance of building. It was designed to stimulate market-based changes in building practices and has successfully been adopted by a wide array of public and private sector leaders" (p. 2).

"Eco-labels are appealing to manufacturers as a marketing tool because they can convey environmental qualities without revealing proprietary information. They are often appealing to environmental advocates as a policy tool, based on the assumption that informed consumers will stimulate market demand for environmental products, driving manufacturers to compete for environmental performance" (p. 12).

"While it may be desirable from an implementation perspective to create an eco-label for whole buildings there are complications because the product of the construction 
industry is too complex to satisfactorily give eco-labels to buildings. However the power of an eco-label to create market change cannot be ignored. Both consumers and industry would like to see a building assessment tool that is sufficiently robust to be valid and one that can facilitate decision-making at key stages in the process. But in order to be useful, results of an assessment must be simple to understand and easily communicated" (p. 13).

\subsection{Recent Dutch developments}

\subsubsection{Basis for the labeling system}

There are several building assessment tools in the Netherlands. GreenCalc and GPR building have already been mentioned; two others are Eco-Quantum and the Toolkit Sustainable Building. At the recent conference on GPR building (see Sect. 2.4), the initiators of these four tools announced the launch of a project to gear all tools to one another and make them comparable. Ultimately, this project should enhance the communicative quality of the tools, making them more effective in providing public information. A shared method and database, to be presented in July 2007, could create a basis for the desired labeling system.

\subsubsection{Case of Oost Flevoland Woondiensten (OFW) (Sweringa and Levenbach 2006)}

OFW is a housing corporation specializing in affordable housing; it owns 4,600 rental units. As OFW is the first Dutch housing corporation to apply energy labeling, its experiences with the energy labeling system make for a suitable case study. That system earned the corporation an honorable mention in the competition for the Dutch Energy Award 2006.

The goal of OFW's strategic policy is to reduce the cost of living for their clients. Over the past few years, energy expenditure has risen more than rents (see Fig. 1). In the Netherlands rents are income-dependent for lower-income households. Energy prices, however, are the same for everyone. This results in a growing pressure of energy expenditure on real disposable income (see Figs. 2 and 3). Therefore, OFW gives energy efficiency high priority. According to the director of the housing corporation, G. Sweringa, climate change and care for the environment are key issues for many of the people working at OFW. However, these are not of particular interest to the clients. For them, the key housing issues besides the cost of living are location, social environment (noise nuisance for example), type and quality of the house, and services. Communication about energy efficiency with the clients therefore only concerns housing expenses. For OFW, a continuous improvement of the housing stock, with a concomitant increase in energy efficiency, is imperative. Not only does this lower the housing expenses but it results in a healthier indoor environment and more comfort for the tenants.

According to the European Union Energy Performance of Buildings Directive (EU EPBD), all European countries should have implemented an energy certification system, applicable to all transactions on dwellings and other buildings, by January 1 2006. This certification system should show the present energy performance of the building and offer suggestions for improvements. Ever since the Dutch government asked for postponement, it has remained unclear what the Dutch system would involve. Almost all housing corporations in the Netherlands are still waiting for this official national system. OFW, 


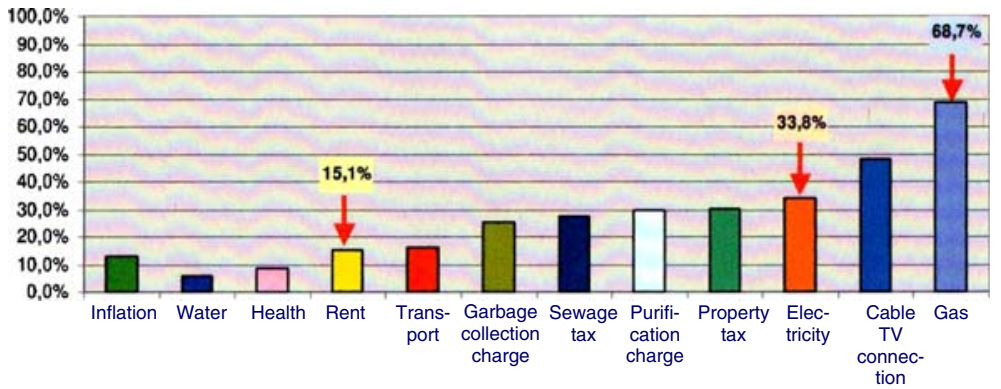

Fig. 1 Inflation and living expenses 2005. During the last 5 years the raise of the rentals costs was $15.1 \%$, the raise of the electricity costs $33.8 \%$ and the raise of gas costs $68.7 \%$. This is much more than the raise of the inflation

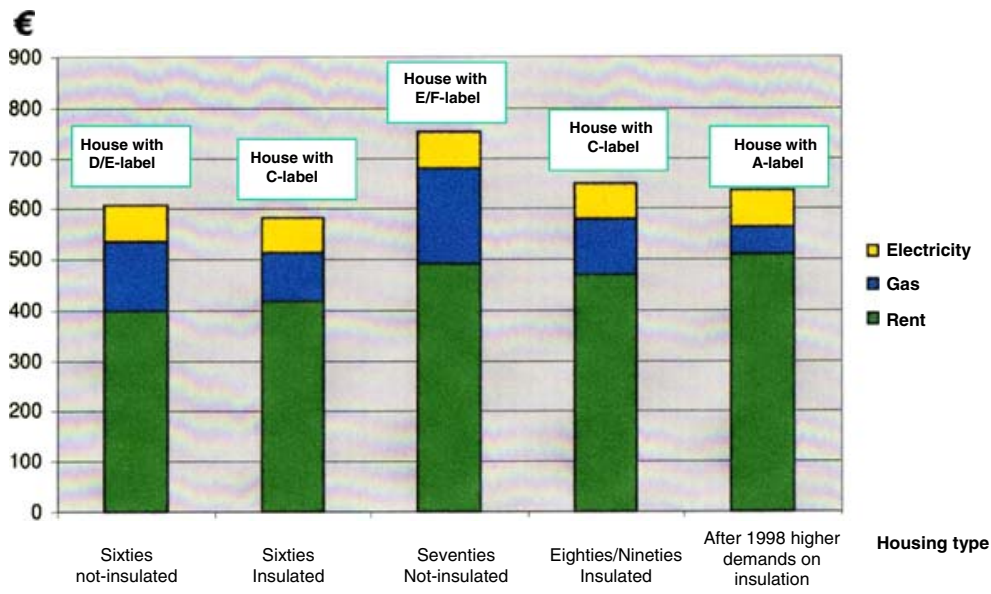

Fig. 2 Living expenses. Source OFW

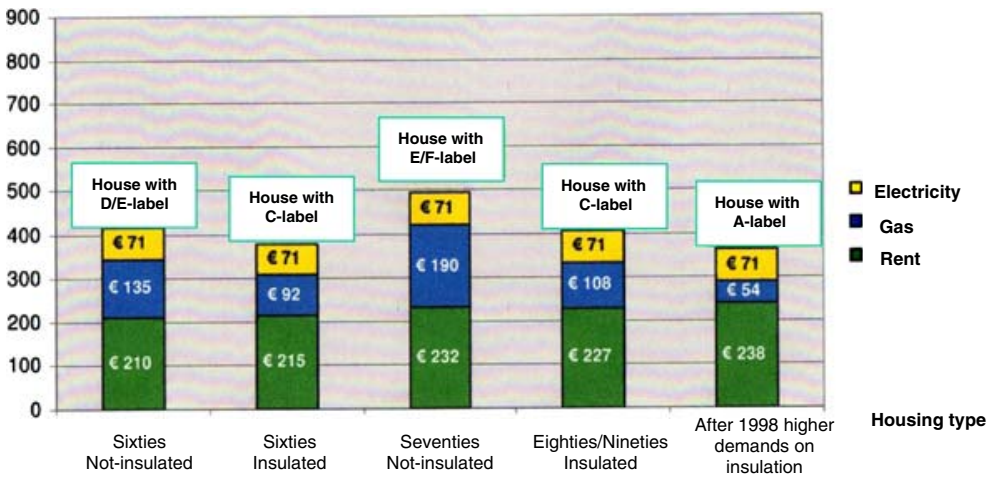

Fig. 3 Living expenses for the lower incomes (18,000€/year) with income dependent rents 
however, acting in their clients' interest, already got started. They decided to use the certification and labeling system that ESCN (Energy ServiceCenter Netherlands) designed to improve communication with clients on the topic of energy.

The system, called ESCN Energy Performance Labels $\mathbb{R}$, assigns seven categories, A-G. Class $\mathrm{A}$ is the best and means the building is extremely energy-efficient (Dutch energy index $<0.60$ ), whereas class $\mathrm{G}$ is extremely bad and means the building is energyinefficient (Dutch energy index $>1.35$ ) (see Fig. 4). Class D is assigned to an average house. The labels are visualized by a color-coded icon of a home with a cloud of smoke rising from a chimney. A green (A-class) home will in theory have a white (clean!) cloud, signifying low $\mathrm{CO}_{2}$ emissions. A red (G-class) home will in theory emit a dark gray cloud, signifying high $\mathrm{CO}_{2}$ emissions.

ESCN is working with OFW and others to develop interactive software combining the theoretical energy performance with the actual energy use. This input can be retrieved manually or via automatic connections with electronic registering systems, which will soon be standard in most homes. The aim of this easy interactive system is to provide feedback and advice to domestic clients. If a tenant is using more energy than expected, the emission cloud of the label will become darker. The user will be asked about his or her heating, cooking, ventilation, and bathing habits and will be offered suggestions for lowering the energy use. Obviously, the system will have built-in safeguards against invasion of privacy.

ESCN uses the Energy Performance Advice methodology that was introduced in the Netherlands in 1999. Thanks to government subsidies, such advice has been very popular. Energy Performance Advisors have inspected over 600,000 homes, which resulted in energy-efficiency reports (EPA) with suggestions for improvement. By the end of 2003, over 140 organizations were certified to produce Energy Performance Advice, while more than 2000 people had studied to become an Energy Performance Advisor. When the subsidies were discontinued in 2004, the amount of Energy Performance Advice being provided declined very quickly. OFW had already made EPAs of all their houses by that time.

Fig. 4 Labeling system. Source OFW

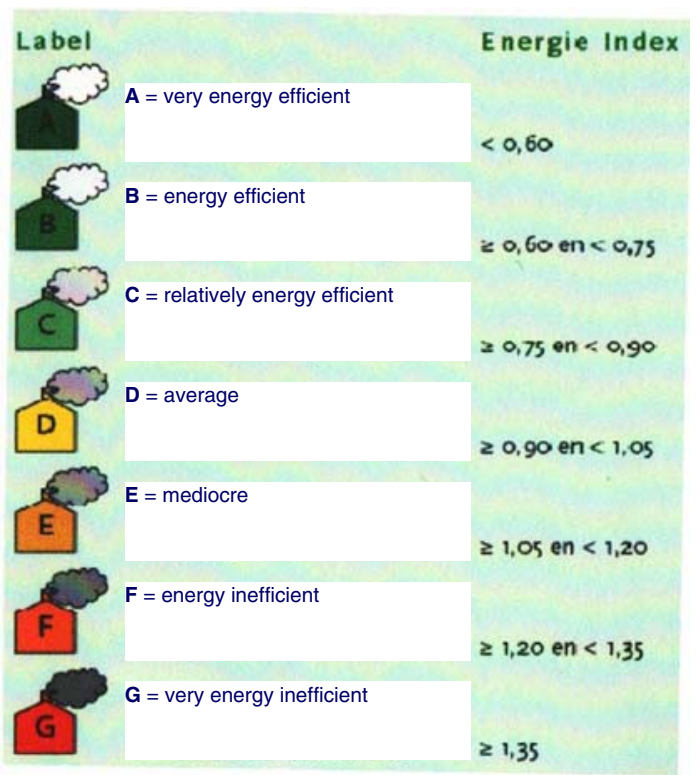


OFW uses the energy-labeling system for several purposes. The first is to provide information. It is directed to the (potential) tenants and it concerns the house itself, but also the tenants' energy-related behavior and the OFW's home-improvement activities. In addition, the system provides grounds for establishing rental policy. It allows the housing corporation to set priorities in its strategic policy plan, to determine the results of energyefficiency measures, and then to relate health issues to energy efficiency.

In its advertisements and publications, OFW shows the labels in the appropriate color along with the homes on offer. When offering a dwelling to a potential tenant, the housing corporation hands over a certificate that shows the energy efficiency of the house. The certificate includes an indication of the expected gas usage. Upon signing the lease, the tenant receives a brochure with information about the relation between consumer behavior and energy savings. The tenant is also given an energy-efficient light bulb to encourage energy- friendly behavior. Dwellings bearing a label with class E, F, or G are subject to half of $1 \%$ less increase in rent than other houses let by OFW. In this way, OFW shows their tenants that they too feel responsible for a low energy bill. The association of tenants very much appreciates these gestures.

Because of its energy labeling system and the availability of EPAs, it is very simple for OFW to communicate the results of its home-improvement activities. For example, for all 4,600 dwellings, the energy-efficiency measures resulted in a reduction of 1.3 million $\mathrm{m}^{3}$ gas and 2.4 million kilos of $\mathrm{CO}_{2}$ emission in 2005. This resulted in an overall reduction of the gas bill by $700,000 €$.

\section{Conclusions}

According to Dutch housing corporations, sustainable housing is more expensive than standard building practices. A study conducted in 2004 proved this to be untrue, however. While it also demonstrated that sustainable building can be financially profitable, there are no general facts and figures on the costs of sustainable housing in the Netherlands to back this up. The reasons for this lack of data are diverse. One is the wide range of options concerning environmental topics and housing typologies; another is the location and the volume of any given housing project. But there are other conditions too that make it difficult to extrapolate from specific measurements to get a general picture. These influences are the following:

- The time span: A focus on the life cycle of a building makes sustainable building more profitable than a focus on the investment stage.

- The ambition level: The more ambitious the level of sustainability, the higher the costs.

- The (hidden) environmental costs: Inclusion of the costs that are necessary to prevent the building from having a negative impact on the environment (hidden environmental costs) instead of the costs necessary for the investment in environmental protection measures that exceed the statutory requirements (environmental costs) completely changes the financial picture.

- The phase in which sustainable building has been put on the agenda: Thinking about the possibilities at an early stage of a project lowers the costs compared to implementing sustainable building in a later phase.

- Benefits from influences on health: With a positive influence of sustainable building measures on human health, a big financial advantage may be achieved. 
The conclusion reached in the 2004 study - that sustainable building can be financially profitable-formed the basis for the new study in 2006. The objective of the latter study was to generate practical solutions to improve the chances of profit. The research question was formulated as follows:

What are some practical and realistic solutions for the problem that the potential positive financial yield of sustainable building is hard to realize?

The answer to this question is focused on housing. In short, the introduction of a labeling system that covers all activities ('one language') is inevitable. A comprehensive labeling system would provide the conditions under which objective communication about quality is possible.

This labeling system should translate sustainability in housing into a manageable and controllable system. In an easily accessible form, it should show the level of sustainability of a specific house. That system could then be used as an umbrella covering all kinds of incentives, from information supply to tax regulations. The underlying building assessment tool should be robust and the results easy to understand. A suitable basis for energy labeling is the EU Energy Performance of Buildings Directive (EPBD). Several building assessment tools are already in use in the Netherlands, and they cover all topics related to sustainability. As of July 2007, a uniform method and database will be introduced. This shared method and database could provide the basis for the desired labeling system, which, going by experiences in the USA, is deemed to have market value.

The case of the housing corporation OFW illustrates how effective a labeling system can be in the Dutch situation. It shows that both 'the market' and the environment can benefit from a simple and unambiguous labeling system. The case also shows what is required to successfully introduce this system in the consumer realm: a clear connection to consumer needs. Furthermore, the case reveals the advisability of implementing the EU $\mathrm{EPBD}$, in light of its suitability as basis for energy labeling. The need to focus on the existing housing stock is confirmed by this case. The relation of the labeling system with other incentives has also been demonstrated. Although none of the proposed eight incentives (see Sect. 3.3) were implemented, the OFW's informative approach and rent-reduction policy are examples of incentives related to the labeling system.

OFW started to introduce the topic of health into its system, but this aspect has not been implemented yet. The four Dutch assessment tools show that other environmental topics can be translated into objective standards too. While the OFW has made great strides toward implementing sustainable solutions, no conclusions can be drawn from this case on the profitability of sustainable housing in general.

\section{References}

About GreenCalc. Retrieved November 29, 2006, from http://www.greencalc.com/en-overgreencalc.html Abrams, J. (2005). The company we keep, reinventing small business for people, community and place. White River Jct.: Chelsea Green Publishing Company.

Andersson, J., Boerstra, A., Clements-Croome, D., Fitzner, K., \& Hanssen, S.O. (2006). In Wargocki, P., \& Seppänen, O. (Eds.), Indoor climate and productivity in offices. Rehva guidebook 6, Rehva.

Boon, G. J., Hoogland, G. J., \& Looze, M. (2004). Eindrapportage onderzoek financieel rendement duurzaam bouwen. Rotterdam: Nationaal Dubocentrum.

Boonstra, C., et al. (2006). Passiefhuizen in Nederland. Boxtel: Aeneas.

Bouwend Nederland, Regieraad Bouw (2005). Vernieuwingsakkoord Regieraad Bouw- Bouwend Nederland. Gouda: Bouwend Nederland, Regieraad Bouw. 
Cats, G., et al. (2003). The costs and financial benefits of green buildings: A report to California's sustainable building task force. Washington: Capital E.

CBS, Gemiddelde tarieven aardgas en elektriciteit. Retrieved December 1, 2006 from: http://www.statline. cbs.nl/StatWeb/Table.asp?HDR=T\&LA=nl\&DM=SLNL\&PA=37359\&D1=0-3,16-20\&D2=10-1\&STB=G1

Dobbelsteen, A. van de (2002). De prijs van duurzaam bouwen. Retrieved November 5, 2006 from: bnb.citg.tudelft.nl/files/publications/Dobbelsteen\%202002\%20-\%20De\%20prijs\%20van\%20 duurzaam\%20bouwen.pdf

GPR building, an introduction, http://www.revit-nweurope.org

Graafland, J., et al. (2005). Visie op transparantie in de bouw, aanbeveling voor Regieraad Bouw. Gouda: PSIBouw.

Hal, A. van (2000). Beyond the demonstration project, the diffusion of environmental innovations in housing (thesis). Best: Aeneas.

Hal, A. van (2002). Amerikaanse toestanden, commerciele kansen voor duurzame woningbouw. Best: Aeneas.

Hal, A. van (2004). Draaiboek bouwen met ambitie. Best: Aeneas.

Hal, A. van (2006). Praktische prikkels, een voorstel ter vergroting van de rentabiliteit van duurzaam bouwen. Utrecht: SenterNovem.

Infoblad (2006a). kosten en baten, de financiële aspecten van duurzaam bouwen, Retrieved August 15, 2006 from http://www.dubocentrum.nl/infobladen/infoblad.php?recID=12

Infoblad (2006b). kosten en baten, de financiële aspecten van duurzaam bouwen, relatie nationale pakketten. Retrieved August 15, 2006 from http://www.dubo-centrum.nl/infobladen/ infoblad.php?recID=12\&item=nationale_pakketten_maatregelen

Infoblad (2006c). kosten en baten, de financiële aspecten van duurzaam bouwen, voorbeelden. Retrieved August 15, 2006 from http://www.dubocentrum.nl/infobladen/infoblad.php?recID=12\&item= voorbeelden

Kansrijk (2006). Nieuwegein, April 26th 2006, KS08. Retrieved May 2, 2006, from: http://www.senternovem.nl/KansRijk/Workshops/Krachtige_Stad/Index.asp

Kasteren, J. van, et al. (2002). Buildings that last, guidelines for strategic thinking. Rotterdam: Nai Publishers.

Müller, G., et al. (2006). Bouwen is vooruitzien, theorie en praktijk van levensduurkosten. Rijswijk: Quantes.

MVO Nederland (2004). Nederland in beweging, Het maatschappelijk verslag. Utrecht: annual report MVO Nederland.

MVO Nederland (2005). Denken en Doen in MVO Nederland, Het maatschappelijk verslag. Utrecht: Annual report MVO Nederland.

Passiefhuis platform België, http://www.passiefhuisplatform.be/index.php?col=/nieuws/archief/2003\& doc=overzicht_38

Poel, B. (2003). Geïntegreerd ontwerpen van duurzame gebouwen loont. Duurzaam Bouwen, 7. Best: Aeneas.

Postel, A. M. (2003). Dubo-concepten in licentie, Duurzaam Bouwen, 7. Best: Aeneas.

Rogers, M. E. (1995). Diffusion of innovations, fourth edition. New York: The Free Press.

Scheuer, C. (2002). Evaluation of LEED using life cycle assesment methods. NIST.

Sunikka, M., \& Claudia, B. (2002). Housing associations and sustainable management; environmental efforts in the Netherlands' social housing sector. Delft: Delft University Press.

Sweringa, G. N., \& Levenbach, W. P. (2006). Retrieved during the conference Gezond Binnen (healthy indoors) November 2, Nieuwegein, The Netherlands, 2006 and from: http://www.gezondbinnen. $\mathrm{nl} /$ actprof02.html (completed with information by e-mail and telephone).

VROM-Raad (2005). Milieu en de kunst van het goede leven, advies voor de toekomstagenda milieu. Den Haag: VROM.

Website USGBC, http://www.usgbc.org/DisplayPage.aspx?CategoryID=19

Willard, B. (2005). The next sustainability wave, p. 59. Gabriola Island: New Society Publishers. 